\title{
AKULTURASI DI KRATON KASEPUHAN \\ DAN MESJID PANJUNAN, CIREBON
}

\section{Oleh: Lucas Partanda Koestoro}

I.

Pendukung kebudayaan adalah manusia. Sejak kelahirannya dan dalam proses sosialisasi, manusia mendapatkan berbagai pengetahuan. Pengetahuan yang didapat dant dipelajari dari lingkungan keluarga pada lingkup kecil dan masyarakat pada lingkup besar, mendasari dan mendorong tingkah lakunya dalam mempertahankan hidup. Sebab manusia tidak bertindak hanya karena adanya dorongan untuk hidup saja, tetapi juga karena suatu desakan baru yang berasal dari budi manusia dan menjadi dasar keseluruhan hidupnya vang dindmakan kebudayaan. Sehingga suatu masyarakat ketika berhadapan dan berinteraksi dengan masyarakat lain dengan kebudayaan yang berlainan, kebudayaan baru tadi tidak langsung diterima apa adanya. Tetapi dinilai dan diseleksi mana yang sesuai dengan kebudayaannya sendiri. Budi manusia yang menilai benda dan kejadian yang beraneka ragam di sekitarnya kemudian memilihnya untuk dijadikan tujuan maupun isi kelakuan budavanya (Sutan Takdir Alisyahbana, tanpa angka tahun: 4 dan 7).

II.

Data sejarah yang sampai pada kita dapat memberikan petunjuk bahwa masa Indonesia-Hindu selanjutnya digantikan oleh masa Islam di Indonesia. Kalau pada masa Indonesia-Hindu pengaruh India menjadi faktor yang utama dalam perkembangan budaya masyarakat Indonesia, maka dalam masa Islam di Indonesia, Islam pun menjadi faktor yang berpengaruh pula. Adapun pola perkembangan kebudayaan Indonesia pada masa masuknya pengaruh Islam, pada dasarnya tidak banyak berbeda dengan apa yang terjadi dalam proses masuknya pengaruh Hindu. Kita jumpai perubahan-perubahan dalam berbagai bidang. Misalnya saja bidang politik, kesenian dan sudah barang tentu dalam bidang kepercayaan.

Kalau dalam masa masuknya pengaruh Hindu di Indonesia perubahan dalam bidang politik terlihat dengan berdirinya kerajaan-kerajaan yang bercorak Hindu seperti Tarumanegara, Mataram (Kuno), Sriwijaya dan sebagainya hingga Majapahit, maka dalam masa masuknya pengaruh Islam perubahan dalam bidang politik juga terlihat dengan mulai berkembangnya kerajaan-kerajaan yang bercorak Islam. Contohnya adalah kerajaan-kerajaan Demak, Cirebon, Aceh, Mataram (Islam) dan sebagainya. Berkembangnya kerajaan-kerajaan yang bercorak Islam tersebut, mempengaruhi pula perkembangan dalam bidang kesenian. Sedangkan perubahan dalam bidang kepercayaan tentu 
saja sangat terasa, dimana suasana ke-Hindu-an telah digantikan dengan suasana ke-Islam-an.

Bila diamati, terlihat bahwa di dalam pergantian tersebut tidak terjadi suatu diskontinuitas. Sebaliknya, masih tetap ada kontinuitas. Kesinambungan tersebut memperlihatkan bahwa masyarakat Indonesia masa itu telah memiliki suatu kemampuan yang tinggi untuk tetap mempertahankan nilai-nilai lama di samping juga menerima yang baru.

III.

Di Cirebon masih terdapat dua kekunaan dari masa pertumbuhan dan perkembangan Islam di Indonesia, yakni Kraton Kasepuhan dan Mesjid Panjunan. Keduanya memperlihatkan adanya kontinuitas dalam proses pergantian dari pengaruh Hindu ke pengaruh Islam. Walaupun hanya terlihat pada seni hias dan seni bangunnya saja, adanya kenyataan ini bisa memberi petunjuk untuk mengetahui lebih banyak tentang kehidupan budaya kala itu.

\section{A. Kraton Kasepuhan}

Di salah satu bagian pokok bangunan Kraton Kasepuhan terdapat sebuah langgar yang biasa disebut dengan nama Langgar Pangrawit. Tiang tunggal yang menopang atap bangunan ini terbuat dari kayu yang dipenuhi dengan ukiran indah. Motif bangunan dengan tiang tunggal seperti ini sudah ada pada tradisi seni hias dan seni bangun jaman Indonesia-Hindu. Hal ini dapat dilihat pada candi Jawi dan candi Kedaton yang memuat relief-relief berbagai bentuk bangunan bertiang tunggal (A.J. Bernet Kempers, 1959: gambar 243-246 dan 311). Di Langgar Pangrawit inipun digunakan umpak (sebagai dasar untuk meletakkan tiang tunggal penopang langgar tersebut) yang terbuat dari batu andesit. Dasar umpak berbentuk segi empat yang masing-masing sisinya diberi hiasan dengan motif padma. Dasar umpak dengan hiasan bermotif seperti ini juga dikenal pemakaiannya sejak jaman Majapahit (Uka Tjandrasasmita, 1975: 94).

Pada bagian yang disebut Bangsal Sitihinggil, jelas juga terlihat adanya pengaruh seni hias dan seni bangun Indonesia-Hindu, yakni pada candi bentar dan beberapa umpak tiang bangunannya (Uka Tiandrasasmita, 1976: 8) (foto 1). Bahkan penamaan Bangsal Sitihinggil sendiripun, seperti juga penamaan ruang atau bagian bangunan Kraton Kasepuhan lainnya, misalnya srimanganti dan prabayaksa, menunjukkan persamaan dengan penamaan bagian-bagian kraton dari masa sebelum kedatangan Islam ke Indonesia (Uka Tjandrasasmita dkk., 1975: 156).

Sebaliknya, pencerminan beberapa konsepsi Islam juga terlihat pada jumlah tiang dari bangunan-bangunan yang terdapat di Bangsal Sitihinggil. Misalnya tiang penopang bangunan Pendawa Lima yang 


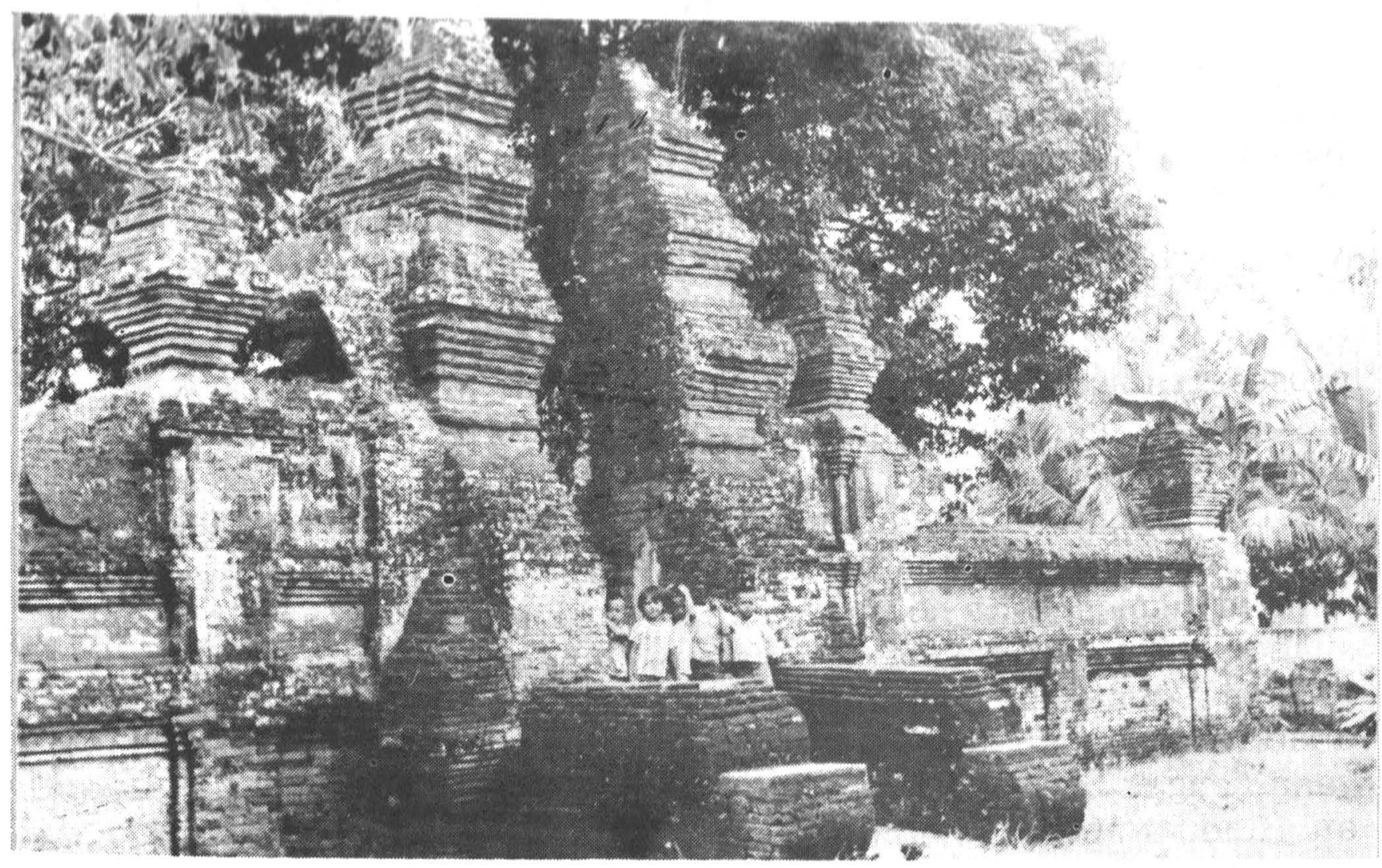

\section{Foto 1:}

\section{Pintu masuk berbentuk candi bentar ke bangsal Sitihinggil, Kraton Kasepuhan.}

jumlahnya ada lima buah sebagai lambang dari Rukun Islam (Uka Tjandrasasmita, 1976: 8).

\section{B. Mesjid Panjunan}

Mesjid ini mempunyai bentuk atap yang biasa disebut atap tumpang. Bangunan dengan bentuk atap seperti ini merupakan suatu kesinambungan dari bangunan meru yang telah dikenal juga pemakaiannya di Indonesia, jauh sebelum Islam masuk. Bentuk meru ini masih banyak dijumpai di Bali dalam berbagai bangunan yang tidak ada hubungannya dengan Islam (G.F. Pijper, 1947: 275). Dari denah bangunan Mesjid Panjunan yang berbentuk persegi, memperlihatkan bahwa seni bangun pada masa pertumbuhan dan perkembangan Islam di Indonesia bukan merupakan bentuk baru yang dibawa oleh orang-orang Islam dari luar Indonesia. Sebab denah persegi seperti ini sangat dikenal pemakaiannya dalam seni bangun candi dari masa kebudayaan Indonesia-Hindu (G.F. Pijper, 1947: 275).

Langgar Pengrawit menggunakan bentuk atap tumpang dan denah persegi, tiang tunggal dengan ukiran indah dan umpak berhias. Pemakaian seni bangun dan seni luas pada tempat peribadatan seperti itu menandakan adanya kesinambungan dalam seni bangun dan seni hias yang disesuaikan dengan latar belakang keagamaan yang baru. 
IV.

Ditinjau secara keseluruhan, apa yang terlihat pada dua kekunaan tersebut pada hakekatnya adalah suatu proses akulturasi. Subyek budayanya masih tetap sama yakni masyarakat Indonesia dengan obyek budaya yang juga sama tetapi berkembang dan diperkaya dengan unsur-unsur Islam. Seperti halnya dengan masa Indonesia-Hindu dimana tidak terjadi proses Hinduisasi, maka dalam perkembangan budaya masyarakat Indonesia masa Indonesia-Islam pun tidak terjadi proses Arabisasi. Adapun pengaruh Arab (Arab sebagai tempat lahirnya agama Islam) merupakan akibat, bukan sebab, dari dipeluknya agama Islam oleh bangsa Indonesia (Snouck Hurgronje, 1973: 17). Apalagi bila diingat bahwa Islam datang ke Indonesia bukan dengan kekerasan, melainkan dengan proses interaksi yang wajar. Untuk memudahkan memasukkan Islam ke dalam pangkuan masyarakat Indonesia, simbol-simbol yang selaras dengan kemampuan penangkapan kulturil setempat dipergunakan. Sebab dari gambaran sejarah berabadabad yang lampau, ternyata bangsa Indonesia telah mengenal kebudayaan dengan berbagai aspeknya. Sehingga ketika gelombang kebudayaan Hindu datang dihadapannya, terjalinlah hubungan kebudayaan yang harmonis. Demikian juga ketika Islam sampai ke Indonesia. Kesemuanya ini memberikan suatu pengaruh yang unik dan kompleks sifatnya bagi kebudayaan Indonesia itu sendiri.

\section{Kepustakaan}

Hurgronje, Snouck,: Islam di Hindia Belanda, Jakarta: Bhratara. 1973

Kempers, A.J. Bernet,: Ancient Indonesian Art, Cambridge, Massachu1959 setts: Harvard University Press.

Pijper, G.F.,: 'The Minaret in Java', India Antiqua, Leyden: Kern Insti1947 tute, hlm 273-283.

Sutan Takdir Alisyahbana,: Perkembangan Sejarah Kebudayaan Indo. nesia Dilihat dari Jurusan Nilai-nilai, Stensilan tanpa nama tempat, penerbit dan angka tahun.

Uka Tjandrasasmita,: "Art de Mojopahit et art du Pasisir", Archipel, 1975 9, Paris: Societe pour l'Etude et la Connaissance du Mon- $₫$ de Unsulinden, hlm 93-98.

Uka Tjandrasasmita, (Ed),: Sejarah Nasional Indonesia, III, Jakarta: 1975 Departemen Pendidikan dan Kebudayaan.

Uka Tjandrasasmita,: 'Sepintas mengenai peninggalan kepurbakalaan

1976 Islam di pesisir utara Jawa", Aspek-aspek Arkeologi Indonesia, 3, Jakarta: Proyek Pelita Pembinaan Kepurbakalaan Dan Peninggalan Nasional. 